\title{
Frequency of hypertension assessed with ambulatory blood pressure monitoring in children with renal damage
}

\author{
Renal hasarlı çocuklarda ayaktan kan basıncı izlemi ile hipertansiyon sıklığı
}

\author{
Seçil CONKAR \\ Ege Üniversitesi Çocuk Hastanesi, Çocuk Anabilim Dalı, Çocuk Nefroloji Kliniğ̈i, İzmir
}

\begin{abstract}
Objective: To determine the frequency of hypertension in children with renal scarring.

Methods: The present study was conducted between February 2013 and April 2015 in the Department of Pediatric Nephrology, Diyarbakır Child's Hospital. A total of 54 pediatric patients (aged 6-17) diagnosed with renal scarring were included in the study. Dimercaptosuccinic acid renal scans were used for the diagnosis of renal scarring. Ambulatory Blood Pressure Monitoring was performed in all patients using a Spacelabs 90217 . We also searched for urinary microalbuminuria.

Results: HT was identified in $7(13 \%)$ patients with renal scarring during the office measurements. On the other hand, $23(42.7 \%)$ patients were found to have hypertension by Ambulatory Blood Pressure Monitoring. Patients showing severe and mild involvements on dimercaptosuccinic acid renal scans were compared in terms of frequency of hypertension and microalbuminuria ; however, no statistically significant difference was found.

Conclusion: Renal scarring presents a risk for hypertension in children. Office blood pressure measurement is insufficient for hypertension detection in children with renal scarring; therefore, Ambulatory Blood Pressure Monitoring should be performed to establish accurate diagnosis.
\end{abstract}

Keywords: Ambulatory blood pressure monitoring, children, hypertension, renal scar

$\ddot{\mathbf{O Z Z}}$

Amaç: Skarlı böbrek olan çocuklarda hipertansiyon sıklığını saptamak.

Yöntem: Bu çalışma, Şubat 2013 - Nisan 2015 tarihleri arasında Diyarbakır Çocuk Hastalıkları Hastanesi Çocuk Nefroloji Biriminde yürütülmüştür. Çalışmaya, renal skar tanısı konan toplam 54 çocuk hasta (yaşları 6-17) dahil edildi. Böbrek skarlanması tanısında Dimercaptosuccinic acid kullanıldı. Tüm hastalarda Spacelabs 90217 kullanılarak ayaktan kan basıncı izlemi uygulandı, ayrıca üriner mikroalbuminüri incelendi.

Bulgular: Ofis ölçümleri sırasında renal skar bulunan 7 hastada (\%13) hipertansiyon belirlendi. Öte yandan, ayaktan kan basıncı izlemi ile $23(\% 42,7)$ sıklıkta hipertansiyon belirlendi. Dimercaptosuccinic acid renal incelemede şiddetli ve hafif tutulum gösteren hastalar, hipertansiyon ve mikroalbüminürisi sıklığı açısından karşılaştırıld. Bununla birlikte, istatistiksel olarak anlamlı fark bulunamadı.

Sonuç: Böbrek hasarlanması, çocuklarda hipertansiyon riski oluşturmaktadır. Renal hasarlı çocuklarda ofis kan basıncı ölçümü hipertansiyon belirlenmesi yetersizdir, bu nedenle doğru tanı koymak için ayaktan kan basıncı izlemi yapılmalıdır.

Anahtar kelimeler: Yaşam içi kan basıncı izlemi, çocuklarda, hipertansiyon, renal skar

Alındığı tarih: 12.06 .2017

Kabul tarihi: 02.11.2017

Yazışma adresi: Uzm. Dr. Seçil Conkar, Ege Üniversitesi Çocuk Hastanesi, İzmir - Türkiye

e-mail: secilcankar@yahoo.com.tr

\section{INTRODUCTION}

The relationship between renal damage and hypertension is well-known ${ }^{(1)}$. The $99 \mathrm{~m}$ technetiumlabeled dimercaptosuccinic acid (DMSA) scan is a renal imaging method which enables determination of renal damage (2). DMSA scan is considered the gold standard for determining renal parenchymal damage. Renal parenchymal damage can be congenital or acquired. Acquired renal damage results from 
pyelonephritis- induced renal Injury. Congenital renal damage may stem from congenital anomaly of the kidney such as hypoplasia and dysplasia. Persistent defect(s) first identified 6 months or more after the acute infection usually indicate renal damage ${ }^{(3)}$. Decrease in the number of nephrons leads to renal damage. As a result, reducing the area of filtration causes hypertension ${ }^{(4)}$. It is thought that children with renal damage may develop hypertension at any stage of life. Hypertension has been reported to occur in $9 \%$ to $30 \%$ of children. The methods for monitorization of blood pressure (BP) in children with renal damage include casual BP measurements, selfmeasured BP, and ambulatory BP monitoring. Ambulatory blood pressure monitoring (ABPM) has advantages: it significantly correlates with the presence of end-organ damage, and identifies abnormal BP patterns. BP changes continually depending on daily activities. Which is a valuable diagnostic tool for the assessment of ABPM, and hypertension. ABPM has become an indispensible clinical and research tool in daily practice. Clinical management recommendations based on outcome studies performed in children are essential for clinicians, as they must decide whether these results require drug therapy for the prevention of target-organ damage, after diagnosing hypertension by ABPM ${ }^{(5)}$. The present study aims to evaluate the relationship between renal damage and hypertension using ABPM in Turkish children.

\section{MATERIALS and METHODS}

We retrospectively reviewed the medical records and DMSA scans of 54 children with renal damage. This study was carried out between February 2013 and April 2015 in the Department of Pediatric Nephrology,Diyarbakır Children's Hospital.Informed consent forms of the study were obtained from each patients' parents. A total of 54 pediatric patients (aged 6-17, body height $>120 \mathrm{~cm}$ ) diagnosed with renal damage were included in the study. All patients with renal scarring were included in the study regardless of the cause of renal scarring. Imaging results were recorded prior to the study. We questioned variables associated with renal damage , including past or present history of hypertension, urinary tract infection (UTI), bladder and bowel dysfunction or prenatal hydronephrosis, nephrolithiasis and vesicoureteral reflux (VUR). All patients underwent ABPM.

Exclusion criteria were presence of acute or chronic illness, or drug treatment (eg, nonsteroidal antiinflammatory drugs, corticosteroids, bronchodilators) within the past 15 days prior to the study entry, since it might affect BP levels . Patients with obesity and under medical treatment for hypertension (HT) were also excluded from the study.

Cortical scarring was defined as persistent defect(s) firstly detected within 6 months on DMSA scans3. Renal scarring was categorized into three groups based on relative uptake of radionuclide by the defective kidney as; mild, focal $>40 \%$, moderate $(20-40 \%)$, and severe $(<20 \%)^{(6)}$.

Office blood pressure (BP) was measured with a stethoscope and sphygmomanometer using a standard auscultatory technique by a physician obtaining at least three valid systolic and diastolic readings. Office BP readings were obtained per participant, and also, all participants had their BPs measured three times in the office. Measurements were averaged when taken on one occasion. BP classification was made after all measurements at different occasions were averaged. Office HT was defined as systolic BP (SBP) or diastolic BP (DBP) levels equal to or above the $95^{\text {th }}$ percentile for age, sex, and height, as set out by the Report of the Second Task Force on Blood Pressure Control in Children ${ }^{(7)}$.

All patients underwent Ambulatory Blood Pressure Monitoring (ABPM) and 24-hour BP monitoring was performed by using a Spacelabs 90217 device (Spacelabs Healthcare, Redmond, WA,USA) at home. The BP cuff which wrapped two thirds of the upper arm was selected and placed on the non-dominant arm of the patient. Measurements were taken every 20 minutes during waking, and every 30 minutes during sleeping hours. Measurements were transferred to a computer program after 24-hour monitoring. Successful monitoring was described as obtaining at least one valid reading for each hour during the 24-hour monitoring period. During the measure- 
ments, the patients were asked to maintain their daily routines and to keep a diary of their daily activities and locations. According to their diary, daytime and nighttime periods were determined as the patients' waking and sleeping hours, respectively. The mean values of 24-hour, daytime, and nighttime BPs were calculated. SBP and DBP loads were determined as the percentage of readings exceeding the $95^{\text {th }}$ percentile for age, sex, and height during each period ${ }^{(8)}$. The readings were compared with the established norms to determine associated BP load, defined as the percentage of valid ambulatory BP measurement above the reference. The reference data was accepted as the smoothed age- and sex-specific $95^{\text {th }}$ percentiles of Wuihl et al. ${ }^{(9)}$ calculated from the original data from Soergel et al. ${ }^{(10)}$. According to ABPM results, the diagnosis of HT was established based on the guidelines of BP load analyses performed using the cut- off value of $25 \%$. The American Heart Association (AHA) updated the values and suggested the criteria for the classification of children as either normotensive or hypertensive masked hypertension by ABPM, after some modifications of the work by Lurbe and colleagues in $2008^{(8)}$.

Patients provided a 24-hr urine collection and they were instructed to report whether the 24-hr collection was complete and whether the urine collection day was inconvenient for them. Microalbumin level was examined by collecting 24-hour urine sample from all patients. Urine microalbumin excretion was measured with an immune turbidometric method (catalogue number: 2K98-20) and Abbott Laboratories' LX-20 device was used. Microalbuminuria was considered when microalbumin level greater than $300 \mathrm{mg} / 24 \mathrm{~h}$ was detected in a 24-hour urine sample.

Statistical analyses were performed using SPSS 15.0 (IBM, Armonk, NY, USA). Definitive analysis, mean and standard deviation and frequency tables were described. Student $t$ test was used for variables following normal distribution in between-group comparisons and in independent groups. Definitive statistics were presented as mean \pm standard deviation. Significance test was performed for advanced statistical analysis (Fisher's exact test, chi-square test), and p-values less than 0.5 was considered to be statistically significant. The correlations between variables were examined using Pearson analysis based on the distribution of the quantitative data.

\section{RESULTS}

Fifty-four children (18 boys and 36 girls) diagnosed with renal scarring were included in the study. Demographic characteristics of the patients are presented in Table 1. Renal scarring was present in 54 patients (right renal scar in 25 patients and left renal scar in 29 cases). Diffuse parenchymal abnormalities and focal scar were seen in $44.4 \%$ and $55.6 \%$ of the patients, respectively.

Patients' average systolic and diastolic BP loads and office blood pressure measurements are shown in Table 1.

Mild $(\mathrm{n}=12 ; 41.6 \%)$, moderate $(\mathrm{n}=25 ; 40 \%)$, and severe $(n=17 ; 47.1 \%)$ renal scars were detected in respective number of renal units. Patients displaying severe and mild renal involvements on DMSA were compared for HT and microalbuminuria frequency; however, no statistically significant difference was found among groups. The highest frequency of HT $(47.1 \%)$ was detected in the severe involvement group on DMSA. The frequency of HT by the involvement grade on DMSA was presented in Table 2.

Table 1. Demographic characteristics and 24-hour ambulatory and official blood pressure measurement values of the patients.
Girls

Boys

Age (yrs)

Height $(\mathrm{cm})$

Weight $(\mathrm{kg})$

BMI $\left(\mathrm{kg} / \mathrm{m}^{2}\right)$

24-h diastolic BP (DBP) load (\%)

24-h systolic BP (SBP) load (\%)

Daytime systolic BP load (\%)

Daytime diastolic BP load (\%)

Nighttime systolic BP load (\%)

Nighttime diastolic BP load (\%)

Office systolic BP (mm Hg)

Office diastolic BP ( $\mathrm{mm} \mathrm{Hg}$ )
$36(66.7 \%)$

$18(33.3 \%)$

$11.57 \pm 3.14$

$142.81 \pm 17.43$

$37.90 \pm 12.28$

$18.09 \pm 2.98$

$24.41 \pm 18.3$

$22.57 \pm 16.68$

$34.42 \pm 12.73$

$23.12 \pm 13.23$

$41.36 \pm 14.42$

$32.48 \pm 13.53$

$107.83 \pm 11.03$

$71.54 \pm 10.07$
BMI: Body mass index, characteristics of the study population (values are means \pm standard deviations) BP: blood pressure, ABPM: ambulatory blood pressure monitoring, values are means \pm standard deviation 
Of all patients with renal scarring, HT was detected in $7(13 \%)$ patients during office BP measurements, whereas 23 patients $(42.5 \%)$ were found to have HT during ABPM ( $\mathrm{p}=0.001$ ) (Table 3). In $42.5 \%$ of the patients with renal scarring HT was found found. In 16 of 54 cases whose BP values were normal during the office blood pressure measurements, were detected to have HT by ABPM. Masked hypertension was detected in $29.6 \%(n=16)$ of the cases. In contrast to the office blood pressure measurements, hypertension was found in 7 of 54 cases by ABPM. Hypertension was detected in 7 of 54 cases both in the office measurements and ABPM. Ambulatory hypertension was encounteredc in $12.9 \%$ of the patients $(n=7)$ (Table 4$)$.

Table 2. Frequency of HT by the renal defects on DMSA.

\begin{tabular}{lccc}
\hline $\begin{array}{l}\text { Renal defect grade } \\
\text { (n) }\end{array}$ & $\begin{array}{c}\text { HT frequency } \\
\text { n (\%) }\end{array}$ & $\begin{array}{c}\text { Microalbuminuria } \\
\text { n }(\%)\end{array}$ & p \\
\hline Severe defect (17) & $8(47.1 \%)$ & $10(58.8 \%)$ & $>0.05$ \\
Moderate defect (25) & $10(40 \%)$ & $15(60 \%)$ & $>0.05$ \\
Mild defect (12) & $5(41.6 \%)$ & $8(66.6 \%)$ & $>0.05$ \\
\hline
\end{tabular}

DMSA: Technetium-labeled dimercaptosuccinic acid, HT: hypertension

Table 3. Frequency of hypertension in patients with renal scarring (n \%)

\begin{tabular}{lcc}
\hline Office BP HT & ABPM HT & p \\
\hline $7(13.0 \%)$ & $23(42.6 \%)$ & 0.001
\end{tabular}

HT: hypertension, ABPM: ambulatory blood pressure monitoring, $B P$ : blood pressure

Table 4. Hypertension types of the patients with renal scarring according to $\mathrm{ABPM}$ and office blood pressure measurements.

\begin{tabular}{lc}
\hline Hypertension type & Number of Cases n (\%) \\
\hline Normal & $31(57.4 \%)$ \\
Hypertension & $23(45.5 \%)$ \\
Masked HT & $16(29.6 \%)$ \\
Ambulatory HT & $7(12.9 \%)$ \\
\hline
\end{tabular}

HT: hypertension

\section{DISCUSSION}

The presence of hypertension is strongly associated with renal damage ${ }^{(11)}$. In one study, $21 \%$ of the children with newly diagnosed hypertension had hypertension etiology showing renal scarring (12). During 27 years of follow-up, Jacobson concluded that the incidence of HT was $23 \%$ in cases with pyelonephritic scars secondary to reflux nephropathy ${ }^{(13)}$. Smellie also reported the incidence of HT as $7.5 \%$ at the end of 18-37 years of follow-up of the patients having symptomatic UTI in childhood ${ }^{(14)}$. In our study, HT frequency was found in $42 \%$ of the children with renal scarring by ABPM, and $13 \%$ by office $\mathrm{BP}$ measurements. We believe that in cases with renal scarring, the frequency of HT is indeed higher than it seems. Patzer et al. ${ }^{(15)}$ revealed that mean systolic day-time BP SDS (standard deviation score) in ABPM was significantly higher in girls with renal scarring compared to healthy subjects. Yavuz et al. ${ }^{(16)}$ found that ABPM was more sensitive than casual BP measurements and might be used for early detection of HT in VUR patients. Routine controls of children with renal scarring should not be limited to office BP measurements, and ABPM should be performed at least once a year.

Different subtypes of renal damage are described in reflux nephropathy ${ }^{(17)}$. Focal cortical scarring, either as a single scar or multiple confluent lesions, usually occurs in the upper or lower pole, and often considered to be the result of pyelonephritic episodes. Renal parenchymal damage which is an acquired scarring, is caused by pyelonephritis- induced renal injury ${ }^{(18)}$.

In the literature, Hodson has been the first to describe the significance of renal scarring in children with recurrent UTI and emphasized the presence of VUR in $97 \%$ of renal scarring cases ${ }^{(19)}$. The etiology of scarring could be related to abnormalities other than UTI and/or VUR. It was possible that VUR was intermittent; and therefore, could not be identified by VCUG $^{(4)}$. Another explanation is that after scar formation, the grade of VUR diminished or resolved. In the same manner, VUR was not found in seven patients who developed renal scarring ${ }^{(20)}$.

Reflux nephropathy has been reported to account for $12 \%$ to $21 \%$ of all pediatric cases with chronic renal failure ${ }^{(21)}$. On the other hand, $9 \%$ to $30 \%$ of children and young adults with renal scarring have 
been reported to have hypertension of which development may take years ${ }^{(22)}$. It is believed that it results from segmental ischemia with increased renin secretion and it does not always depend on the severity of the scarring ${ }^{(23)}$. The survival analysis revealed that approximately $50 \%$ of the children with unilateral and bilateral renal damage develop persistent hypertension around the age of 30 and 22, respectively ${ }^{(24)}$.

Renal parenchymal damage may be associated with proteinuria and with nephrotic syndrome in some cases. In a study performed in children having bilateral VUR with renal scarring and normal creatinine clearance, $53.5 \%$ of these children were detected to have microalbuminuria ${ }^{(25)}$. Microalbuminuria was found in $43 \%$ of the patients with renal scarring.

Our study could not demonstrate any association between the severity of renal scarring and the frequency of HT. Thus, the cases with renal scarring in this study should be assessed as having HT regardless of the severity of renal scars.

Patients with renal scarring may be at the highest risk for hypertension. In children with renal scarring, HT can be diagnosed earlier by ABPM rather than the standard blood pressure measurements; and therefore, timely treatment planning can be made. In all children with renal injury routine ABPM measurements should be made irrespective of office blood pressure measurements.

\section{CONCLUSION}

In conclusion, the present study could reveal a higher incidence of hypertension among patients with renal damage. Children with renal injury had significantly higher ABPMs and increased incidence of hypertension relative to previous studies. This finding shows that children with renal damage are at increased risk of hypertension and should be considered for regular BP screening, preferably with 24-h ABPM.

\section{REFERENCES}

1. Rushton HG Jr. Vesicouretral reflux and renal scarring. In:
Barratt TM, Avner ED, Harmon WE (eds). Pediatric Nephrology. Baltimore: Lippincott Williams \& Wilkins, 1999; 851-72.

2. Gordon I. Indications for $99 \mathrm{~m}$ technetium dimercaptosuccinic acid scan in children. $J$ Urol 1987;137:464-7. https://doi.org/10.1016/S0022-5347(17)44069-9

3. Piepsz A, Blaufox MD, Gordon I, et al. Consensus on renal cortical scintigraphy in children with urinary tract infection. Scientific Committee of Radionuclides in Nephrourology. Semin Nucl Med 1999;29:160-74. https://doi.org/10.1016/S0001-2998(99)80006-3

4. Brenner BM, Garcia DL, Anderson S. Glomeruli and blood pressure. Less of one, more the other? Am J Hypertens 1988;1:335-347. https://doi.org/10.1093/ajh/1.4.335

5. Conkar S, Mir S, Sözeri B, et al. Masked hypertension in children and its relationship with target organ damage. Journal of Clinical and Experimental Investigations 2015;6:102-109. https://doi.org/10.5799/ahinjs.01.2015.02.0498

6. Patel K, Charron M, Hoberman A, Brown ML, Rogers KD. Intra and inter observer variability in interpretation of DMSA scans using a set of standardized criteria. Pediatr Radiol 1993;23:506-509. https://doi.org/10.1007/BF02012131

7. National High Blood Pressure Education Program Working Group on High Blood Pressure in Children and Adolescents. The fourth report on the diagnosis, evaluation, and treatment of high blood pressure in children and adolescents. Pediatrics 2004;114:555-76. https://doi.org/10.1542/peds.114.2.S2.555

8. Lurbe E, Sorof JM, Daniels SR. Clinical and research aspects of ambulatory blood pressure monitoring in children. $J$ Pediatr 2004;144:7-16. https://doi.org/10.1016/j.jpeds.2003.09.050

9. Wühl E, Witte K, Soergel M, Mehls O, Schaefer F; German Working Group on Pediatric Hypertension. Distribution of 24-h ambulatory blood pressure in children: normalized reference values and role of body dimensions. J Hypertens 2003;21:2205-6.

10. Soergel M, Kirschistein M, Busch C, et al. Oscillometric twenty-four- hour ambulatory blood pressure values in healthy children and adolescents: a multicenter trial including 1141 subjects. J Pediatr 1997;130:178-184. https://doi.org/10.1016/S0022-3476(97)70340-8

11. Silva JM, Santos Diniz JS, Marino VS, et al. Clinical course of 735 children and adolescents with primary vesicoureteral reflux. Pediatr Nephrol 2006;21:981-8. https://doi.org/10.1007/s00467-006-0151-1

12. Ahmed M, Eggleston D, Kapur G, Jain A, Valentini RP, Mattoo TK. Dimercaptosuccinic acid (DMSA) renal scan in the evaluation of hypertension in children. Pediatr Nephrol 2008;23:435-8. https://doi.org/10.1007/s00467-007-0656-2

13. Jacobson SH, Eklof O, Eriksson CG, Lins LE, Tidgren B, Winberg J. Development of hypertension and uraemia after pyelonephritis in childhood: 27 year follow up. $\mathrm{Br}$ Med $\mathrm{J}$ 1989;299:703-706. https://doi.org/10.1136/bmj.299.6701.703

14. Smellie JM, Prescod NP, Shaw PJ, Risdon RA, Bryant TN. Childhood reflux and urinary infection: A follow-up of 10-41 years in 226 adults. Pediatr Nephrol 1998;12:727-736. https://doi.org/10.1007/s004670050535

15. Patzer L, Seeman T, Luck C, Wühl E, Janda J, Misselwitz J. 
Day- and night-time blood pressure elevation in children with higher grades of renal scarring. J Pediatr 2003;142:11726. https://doi.org/10.1067/mpd.2003.13

16. Yavuz S, Anarat A, Bayazit AK. Ambulatory blood pressure monitoring in children with vesicoureteral reflux. Urology 2014;83:899-903.

https://doi.org/10.1016/j.urology.2013.10.008

17. Farnsworth RH, Rossleigh MA, Leighton DM, Bass SJ, Rosenberg AR. The detection of reflux nephropathy in infants by $99 \mathrm{~m}$-technetium dimercaptosuccinic acid studies. J Urol 1991;145:542-6. https://doi.org/10.1016/S0022-5347(17)38391-X

18. Polito C, La Manna A, Rambaldi PF, Nappi B, Mansi L, Di Toro R. High incidence of a generally small kidney and primary vesicoureteral reflux. J Urol 2000;164:479-82. https://doi.org/10.1016/S0022-5347(05)67404-6

19. Hodson CJ. The radiologic diagnosis of pyelonephritis. Proc $R$ Soc Med 1959;52:669-672.

20. Lee JH, Son CH, Lee MS, Park YS. Vesicoureteral reflux increases the risk of renal scars: a study of unilateral reflux. Pediatr Nephrol 2006;21:1281-4. https://doi.org/10.1007/s00467-006-0147-x

21. Deleau J, Andre JL, Briancon S, Musse JP. Chronic renal failure in children:an epidemiological survey in Lorraine (France) 1975-1990. Pediatr Nephrol 1994;8:472-6. https://doi.org/10.1007/BF00856534

22. Wennerstrom M. Ambulatory blood pressure 16-26 years after the first urinary tract infection in childhood. J Hypertens 2000;18:485-91. https://doi.org/10.1097/00004872-200018040-00019

23. Stecker JF Jr, Read BP, Poutasse EF. Pediatric hypertension as a delayed sequela of reflux-induced chronic pyelonephritis. J Urol 1977;118:644-6. https://doi.org/10.1016/S0022-5347(17)58137-9

24. Mattoo TK. Vesicoureteral reflux and reflux nephropathy. Adv Chronic Kidney Dis 2011;18:348-54. https://doi.org/10.1053/j.ackd.2011.07.006

25. Coppo R, Porcellini MG, Gianoglio B, Alessi D, Peruzzi L, Amore A, Bianchi M, Lace R, Cavalli G, Amprimo MC. Glomerular permselectivity to macromolecules in reflux nephropathy: microalbuminuria during acute hyperfiltration due to aminoacid infusion. Clin Nephrol 1993;40:299-307. 